NASA/TM-2006-214121

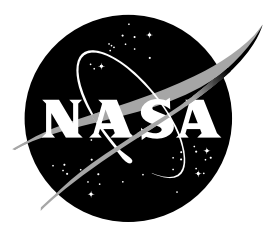

\title{
A Comparison of Coolant Options for Brayton Power Conversion Heat Rejection Systems
}

John Siamidis

Analex Corporation, Brook Park, Ohio

Lee S. Mason

Glenn Research Center, Cleveland, Ohio 
Since its founding, NASA has been dedicated to the advancement of aeronautics and space science. The NASA Scientific and Technical Information (STI) Program Office plays a key part in helping NASA maintain this important role.

The NASA STI Program Office is operated by Langley Research Center, the Lead Center for NASA's scientific and technical information. The NASA STI Program Office provides access to the NASA STI Database, the largest collection of aeronautical and space science STI in the world. The Program Office is also NASA's institutional mechanism for disseminating the results of its research and development activities. These results are published by NASA in the NASA STI Report Series, which includes the following report types:

- $\quad$ TECHNICAL PUBLICATION. Reports of completed research or a major significant phase of research that present the results of NASA programs and include extensive data or theoretical analysis. Includes compilations of significant scientific and technical data and information deemed to be of continuing reference value. NASA's counterpart of peerreviewed formal professional papers but has less stringent limitations on manuscript length and extent of graphic presentations.

- TECHNICAL MEMORANDUM. Scientific and technical findings that are preliminary or of specialized interest, e.g., quick release reports, working papers, and bibliographies that contain minimal annotation. Does not contain extensive analysis.

- CONTRACTOR REPORT. Scientific and technical findings by NASA-sponsored contractors and grantees.
- CONFERENCE PUBLICATION. Collected papers from scientific and technical conferences, symposia, seminars, or other meetings sponsored or cosponsored by NASA.

- SPECIAL PUBLICATION. Scientific, technical, or historical information from NASA programs, projects, and missions, often concerned with subjects having substantial public interest.

- TECHNICAL TRANSLATION. Englishlanguage translations of foreign scientific and technical material pertinent to NASA's mission.

Specialized services that complement the STI Program Office's diverse offerings include creating custom thesauri, building customized databases, organizing and publishing research results ... even providing videos.

For more information about the NASA STI Program Office, see the following:

- Access the NASA STI Program Home Page at http://www.sti.nasa.gov

- E-mail your question via the Internet to help@sti.nasa.gov

- Fax your question to the NASA Access Help Desk at 301-621-0134

- Telephone the NASA Access Help Desk at 301-621-0390

- Write to:

NASA Access Help Desk

NASA Center for AeroSpace Information 7121 Standard Drive

Hanover, MD 21076 
NASA/TM-2006-214121

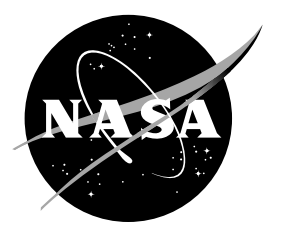

\section{A Comparison of Coolant Options for Brayton Power Conversion Heat Rejection Systems}

John Siamidis

Analex Corporation, Brook Park, Ohio

Lee S. Mason

Glenn Research Center, Cleveland, Ohio

Prepared for the

Space Technology and Applications International Forum (STAIF-2006)

sponsored by the University of New Mexico's Institute for Space and Nuclear Power Studies (UNM-ISNPS)

Albuquerque, New Mexico, February 12-16, 2006

National Aeronautics and

Space Administration

Glenn Research Center 


\section{Acknowledgments}

The work described in this paper was performed for the NASA Exploration Systems Mission Directorate and the Prometheus Nuclear Systems and Technology Program.

This report contains preliminary

findings, subject to revision as analysis proceeds.

Trade names or manufacturers' names are used in this report for identification only. This usage does not constitute an official endorsement, either expressed or implied, by the National Aeronautics and Space Administration.

Available from

NASA Center for Aerospace Information 7121 Standard Drive

Hanover, MD 21076
National Technical Information Service 5285 Port Royal Road Springfield, VA 22100 


\title{
A Comparison of Coolant Options for Brayton Power Conversion Heat Rejection Systems
}

\author{
John Siamidis \\ Analex Corporation \\ Cleveland, Ohio 44135 \\ Lee Mason \\ National Aeronautics and Space Administration \\ Glenn Research Center \\ Cleveland, Ohio 44135
}

\begin{abstract}
This paper describes potential heat rejection design concepts for Brayton power conversion systems. Brayton conversion systems are currently under study by NASA for Nuclear Electric Propulsion (NEP) and surface power applications. The Brayton Heat Rejection Subsystem (HRS) must dissipate waste heat generated by the power conversion system due to inefficiencies in the thermal-to-electric conversion process. Sodium potassium ( $\mathrm{NaK})$ and $\mathrm{H}_{2} \mathrm{O}$ are two coolant working fluids that have been investigated in the design of a pumped loop and heat pipe space HRS. In general $\mathrm{NaK}$ systems are high temperature ( 300 to $1000 \mathrm{~K}$ ) low pressure systems, and $\mathrm{H}_{2} \mathrm{O}$ systems are low temperature ( 300 to $600 \mathrm{~K}$ ) high pressure systems. $\mathrm{NaK}$ is an alkali metal with health and safety hazards that require special handling procedures. On the other hand, $\mathrm{H}_{2} \mathrm{O}$ is a common fluid, with no health hazards and no special handling procedures. This paper compares $\mathrm{NaK}$ and $\mathrm{H}_{2} \mathrm{O}$ for the HRS pumped loop coolant working fluid. A detailed Microsoft ${ }^{\circledR}$ Excel (Microsoft Corporation, Redmond, WA) analytical model, HRS_Opt, was developed to evaluate the various HRS design parameters. It is capable of analyzing $\mathrm{NaK}$ or $\mathrm{H}_{2} \mathrm{O}$ coolant, parallel or series flow configurations, and numerous combinations of other key parameters (heat pipe spacing, diameter and radial flux, radiator facesheet thickness, fluid duct system pressure drop, system rejected power, etc.) of the HRS. This paper compares NaK against water for the HRS coolant working fluid with respect to the relative mass, performance, design and implementation issues between the two fluids.
\end{abstract}

\section{Introduction}

Nuclear Electric Propulsion (NEP) is a technology of current interest because it has the potential to provide many benefits for deep space science missions including maneuverability to multiple mission targets, extended duration science, increased instrument power, and high data rate communications. Surface reactors may be used for the moon or Mars to power human outposts enabling extended stays, insitu resource utilization, and closed loop life support. In either case, the reactor power system (reactor, power conversion, and heat rejection), is a critical element. Closed Brayton Cycle (CBC) converters are one of several promising options for power conversion within a reactor system. The Heat Rejection Subsystem (HRS) must dissipate waste heat generated by the Power Conversion Subsystem (PCS) due to inefficiencies in the thermal-to-electric conversion process. Brayton systems tend to optimize at efficiencies of about 20 to 25 percent with radiator temperatures in the 400 to $600 \mathrm{~K}$ range.

Two previous design studies examined a possible heat rejection concept for a $100 \mathrm{kWe}$ Brayton PCS for the proposed Jupiter Icy Moons Orbiter (JIMO) mission (Mason, 2003; Siamidis, 2005).

In the first design study (Mason, 2003) the PCS included two $100 \mathrm{kWe}$ Brayton converters for a $100 \mathrm{kWe}$ net output power. The HRS consisted of a pumped sodium-potassium (NaK) heat transport loop coupled to a water heat pipe radiator as shown in figure 1 . The total radiator area was $170 \mathrm{~m}^{2}$ configured in two separate wings that extended radially from a central truss structure. The radiator panels provided 


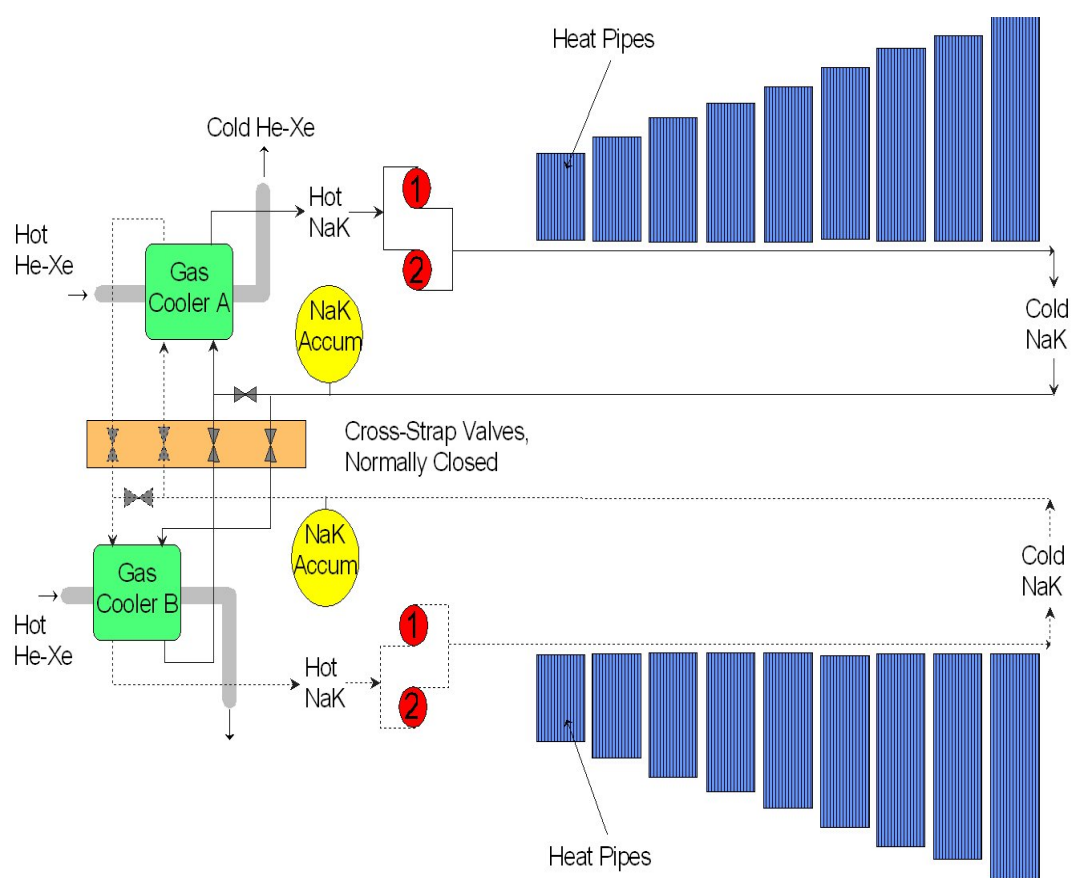

Figure 1.-Two Brayton heat rejection subsystem schematic.

two-sided heat rejection and were arranged in a "stair-case" configuration contained within a $10^{\circ}$ halfangle as dictated by the conical reactor shield. Each radiator wing was dedicated to a single Brayton converter operating at 50 percent of rated power. Cross-strap NaK piping and a dual passage waste heat exchanger, allowed the full radiator (both wings) to serve a single Brayton converter operating at 100 percent power should a failure occur. The total mass of the HRS including radiator panels, pumps, plumbing, and deployment structure was reported as $854 \mathrm{~kg}$, or $5 \mathrm{~kg} / \mathrm{m}^{2}$ (based on total surface area).

In the second design study (Siamidis, 2005) the PCS included four $50 \mathrm{kWe}$ Brayton converters for a $100 \mathrm{kWe}$ system. The HRS consisted of a pumped NaK heat transport loop coupled to a water heat pipe radiator as shown in figure 2. The radiator area was configured in two separate wings that extended radially from a central truss structure. The radiator panels provided two-sided heat rejection and were arranged in a "two-fold" configuration contained within a $10^{\circ}$ half-angle as dictated by the conical reactor shield. Each radiator wing was dedicated to a single Brayton converter operating at 100 percent of rated power with the capability to service either or two Brayton units associated with that wing. The paper discussed the interplay between heat pipe spacing and heat pipe diameter and their effect on heat pipe maximum heat flux, maximum heat pipe power, heat pipe area exposed to micrometeoroid and orbital debris (MMOD), system pressure drop and pump power for a fixed geometry radiator.

This paper uses the previous design concept (Siamidis, 2005) as a starting point for more rigorous definition of the Brayton HRS. Specifically, the paper evaluates two heat transport working fluids (NaK-55 and $\mathrm{H}_{2} \mathrm{O}$ ) for several system pressure drops and for several radiator inlet outlet temperatures.

$\mathrm{NaK}$ and $\mathrm{H}_{2} \mathrm{O}$ are two coolant working fluids that have been investigated in the design of a pumped loop and heat pipe space HRS. In general NaK systems are high temperature (300 to $1000 \mathrm{~K}$ ) low pressure systems, and $\mathrm{H}_{2} \mathrm{O}$ systems are low temperature ( 300 to $600 \mathrm{~K}$ ) high pressure systems. NaK is an alkali metal with health and safety hazards that require special handling procedures. On the other hand, $\mathrm{H}_{2} \mathrm{O}$ is a common fluid, with no health hazards and no special handling procedures. Historically the design of pumped loop and heat pipe space HRS used NaK-78 as the coolant fluid. For the present JIMO application NaK-55 was chosen over NaK-78 for its lower freeze-temperature $(280 \mathrm{~K})$ and higher specific heat. 


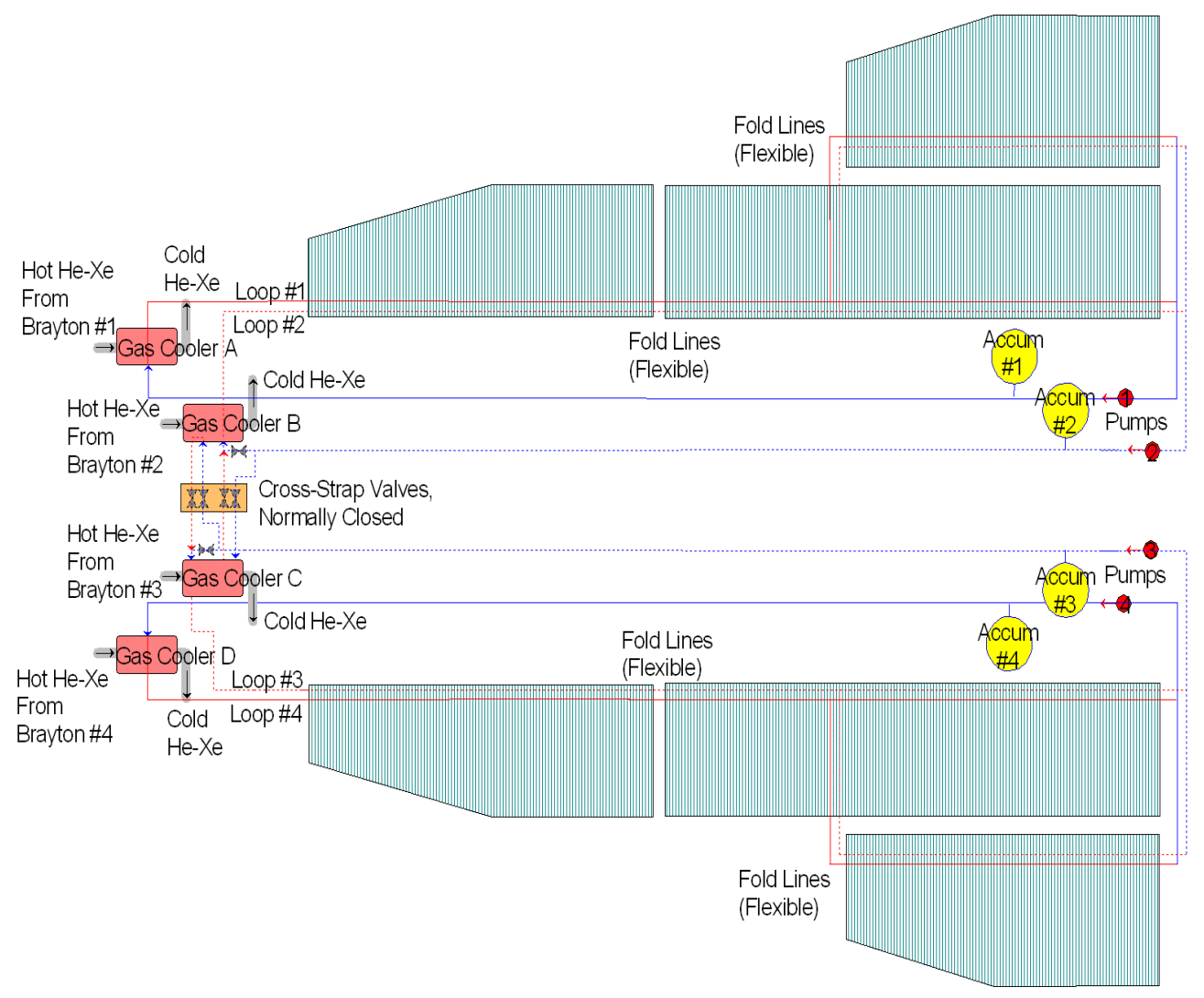

Figure 2.-Four Brayton heat rejection subsystem schematic.

The previous design concept (Siamidis, 2005) for JIMO has been updated. The PCS includes four $100 \mathrm{kWe}$ Brayton converters to produce $200 \mathrm{kWe}$ net output. The HRS consists of a pumped $\mathrm{NaK}$ or $\mathrm{H}_{2} \mathrm{O}$ heat transport loop coupled to a water heat pipe radiator as shown in figure 3 . The radiator area is configured in two separate wings that extend radially from a central truss structure. The radiator panels provide two-sided heat rejection and are arranged in a four boom/segment configuration contained within a $12^{\circ}$ half-angle as dictated by the conical reactor shield. Under nominal operations one pumped-fluid loop is used to transport the waste heat from the gas-cooler of each of the two operating PCS units to a series of radiator panels containing water heat pipes and white-painted carbon-carbon (C-C) radiator fins. A separate, isolated pumped-fluid loop is provided for each of the two non-operating PCS units should a PCS-string switchover become necessary through a failure or anomaly condition. The HRS fluid loops of one operating and one non-operating PCS unit share the same radiator area for single-fault tolerance against failure of either the PCS unit or HRS fluid loop without loss of power generating capabilities. 

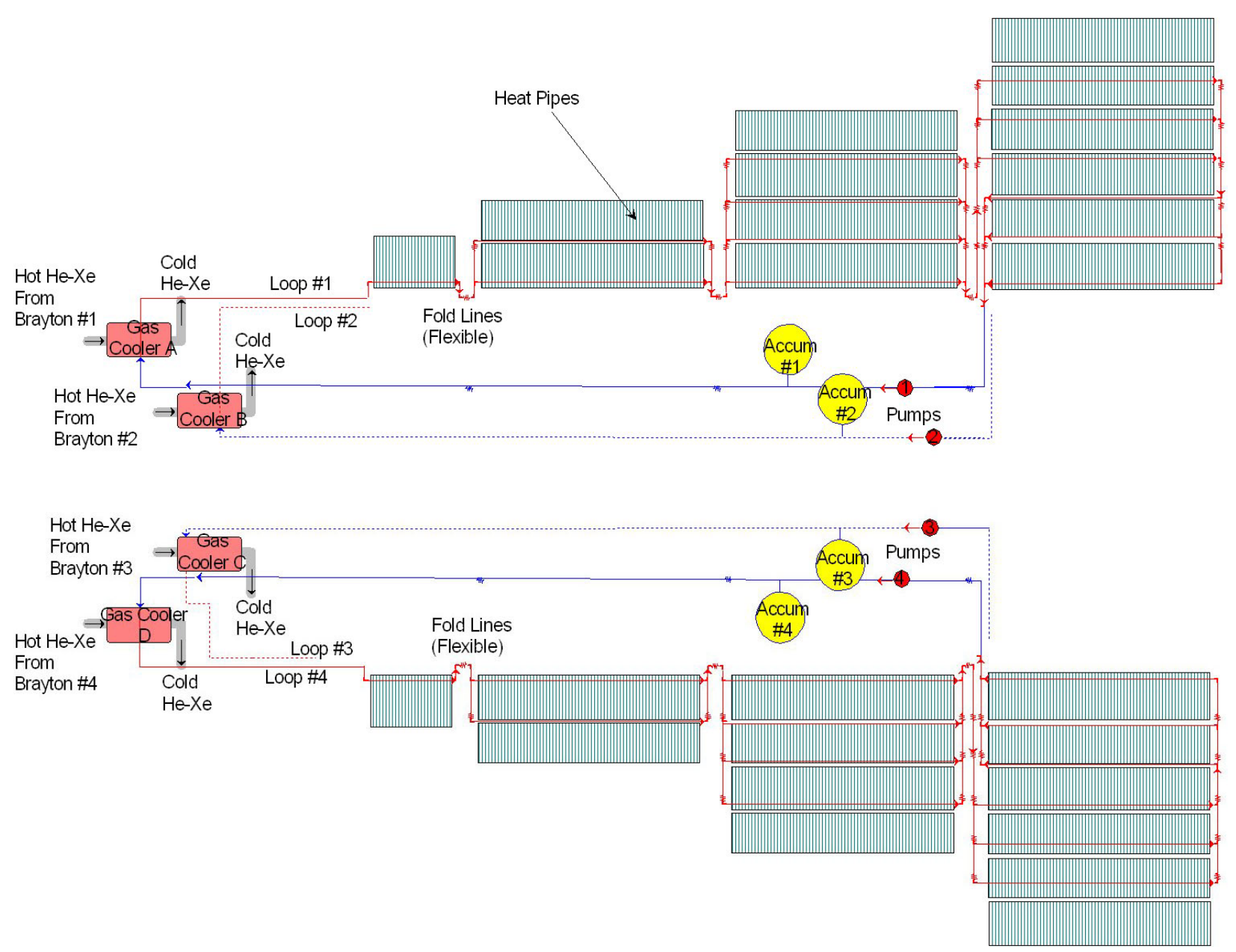

Figure 3.-Updated Brayton heat rejection subsystem schematic.

\section{HRS Design Basis}

The HRS accepts heat from the Brayton power converters and rejects it into space through the radiator panels. A NaK-55 or $\mathrm{H}_{2} \mathrm{O}$ cooling loop connects the Brayton converters to the radiator panels. The Brayton gas coolers serve as the thermal interface to the coolant loops. The design was modified from four $50 \mathrm{kWe}$ Brayton converters to four $100 \mathrm{kWe}$ Brayton converters, each having its own dedicated cooling loop. During nominal operation, only two of the four converters are used to produce the required $200 \mathrm{kWe}$. The radiator panels use a construction consisting of regularly-spaced circular heat pipes contained within two composite facesheets as shown in figure 4. 


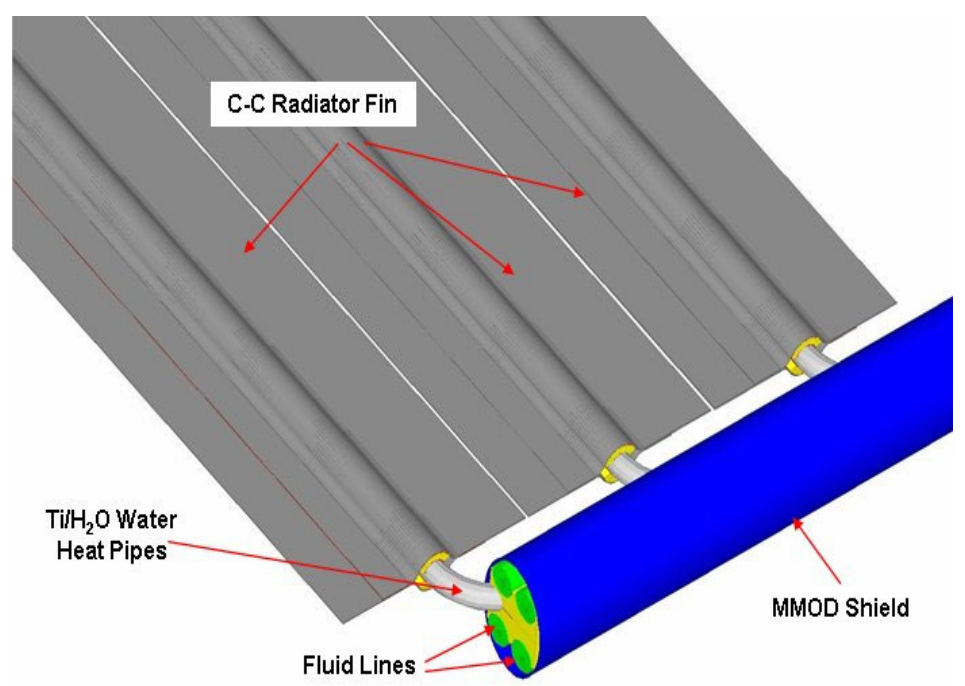

(a) Radiator details

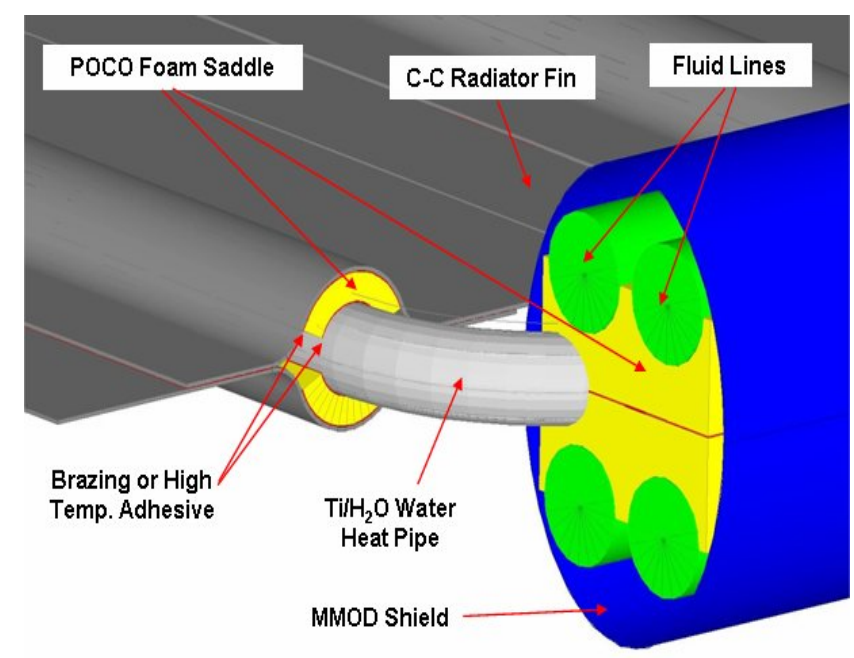

(b) Radiator/cooling loop details

Figure 4.- Radiator detail and heat pipe integration with cooling loop.

The heat pipes use water as the working fluid and titanium containment. Heat pipes provide an efficient means of spreading the heat across the radiator surface with minimal temperature drop. The high conductivity composite facesheets serve as the radiator fin. The heat pipes are thermally connected to the facesheets through a Poco ${ }^{\mathrm{TM}}$ (Poco Graphite, Inc., Decatur, TX) foam saddle extending along the entire axial length of the heat pipe. The saddle provides compliance to address fin-heat pipe thermal expansion and a degree of micrometeoroid shielding. The heat pipe-to-saddle and saddle-to-facesheet bond is accomplished through brazing or high temperature thermal adhesive. One of the key advantages to this type of radiator is its ability to withstand damage from micrometeoroid and orbital debris (MMOD). A fatal MMOD impact to a single heat pipe, even though it will result in the failure of that heat pipe, would have minimal system performance impact.

The water heat pipes interface to the coolant through curved sections partially contained within the cooling loop as shown in figure 5. The heat pipe evaporators are "sandwiched" between two cooling loops. One loop is active and the second is the backup. A Poco foam saddle is introduced between the 

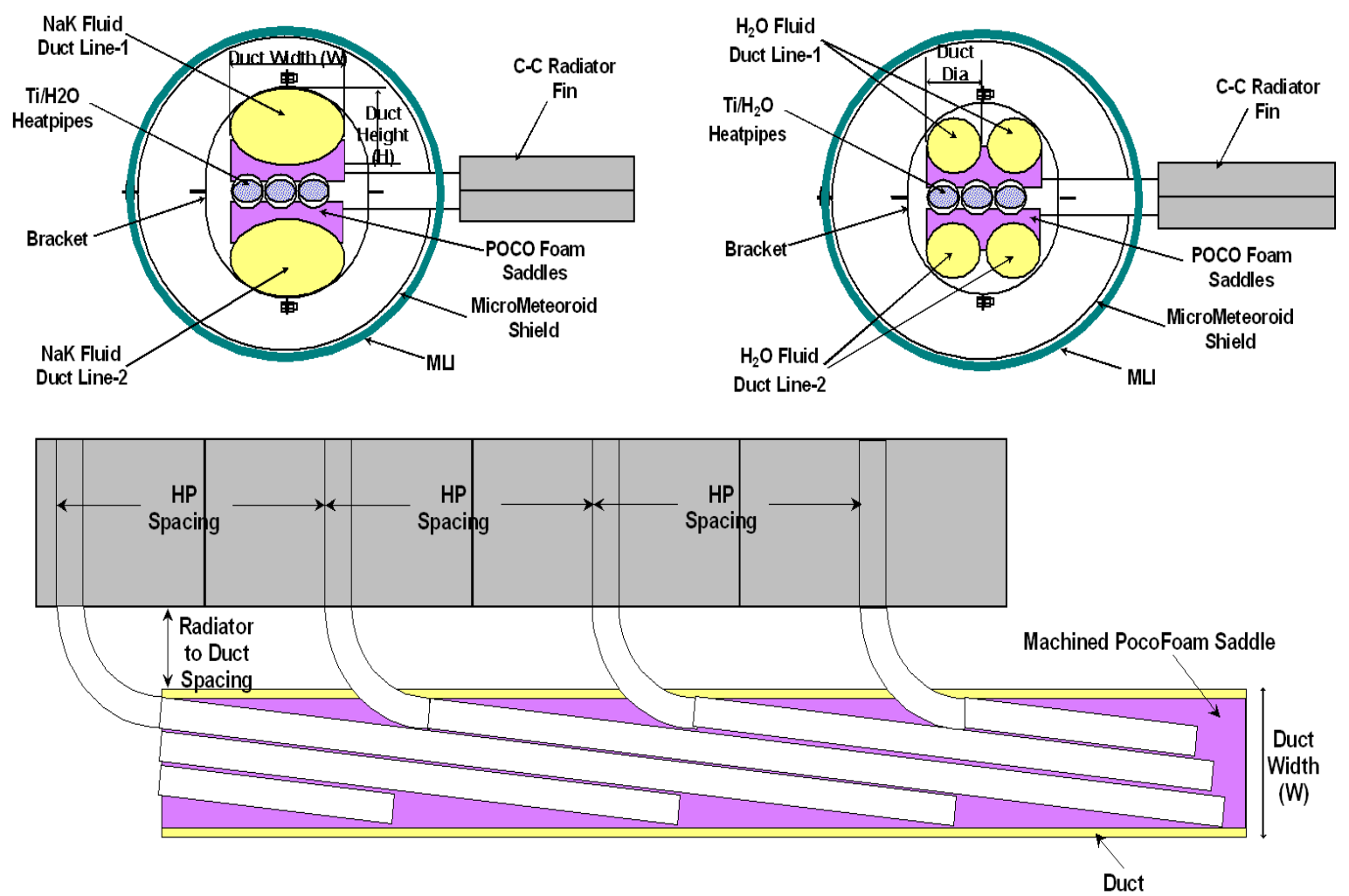

Figure 5.- - Heat pipe integration with cooling loop.

heat pipe evaporators and the cooling loop ducts to improve heat transfer. The two HRS fluid loops provide fault tolerance against loss of either a PCS unit or HRS fluid loop without affecting power generating capabilities. The fluid ducting is made of titanium. The duct cross-section is oval for NaK-55 and split circular for $\mathrm{H}_{2} \mathrm{O}$. Each cooling loop includes a pump and a bellows accumulator.

\section{Analytical Model}

The design of the Brayton HRS depends on many parameters. An Excel spreadsheet model, called HRS-Opt, was developed to evaluate the design trade space described in the previous design study (Siamidis, 2005). Parameters were varied to compare the design options on the basis of pump system pressure drop and required pump power, heat pipe unit power and radial flux, radiator panel areal mass, and overall HRS mass. For the analysis presented in this paper, the HRS-Opt spreadsheet model was modified to accommodate the updated HRS design. Additional capabilities, including NaK-55 and $\mathrm{H}_{2} \mathrm{O}$ coolant properties, were also added.

The fin efficiency is a critical part of this analysis since it varies widely with heat pipe spacing and facesheet thickness. A closed-form equation for fin efficiency (Gilmore, 1994) was adopted in HRS-Opt, as discussed in the previous design study (Siamidis, 2005).

The calculation of fluid loop system pressure drop was simplified from that required in the previous design (Siamidis, 2005). The previous design used heat pipe evaporators immersed within the fluid loop, oriented normal to the fluid flow. A computational fluid dynamics code (CFD Ace ${ }^{\mathrm{TM}}$, CFD Research Corporation, Huntsville, AL) was necessary to generate pressure drop parameters for use in HRS-Opt. The updated concept removes the heat pipes from the flow path, simplifying the flow geometry. Thus, a closed form fluid loop pressure drop calculation is possible. A simple equation, $\left[\Delta P=f *(L / d) * \mathbf{r} *\left(u^{2} / 2\right)\right]$, (Holman, 1981) was used to calculate the system pressure drop in the coolant duct. 


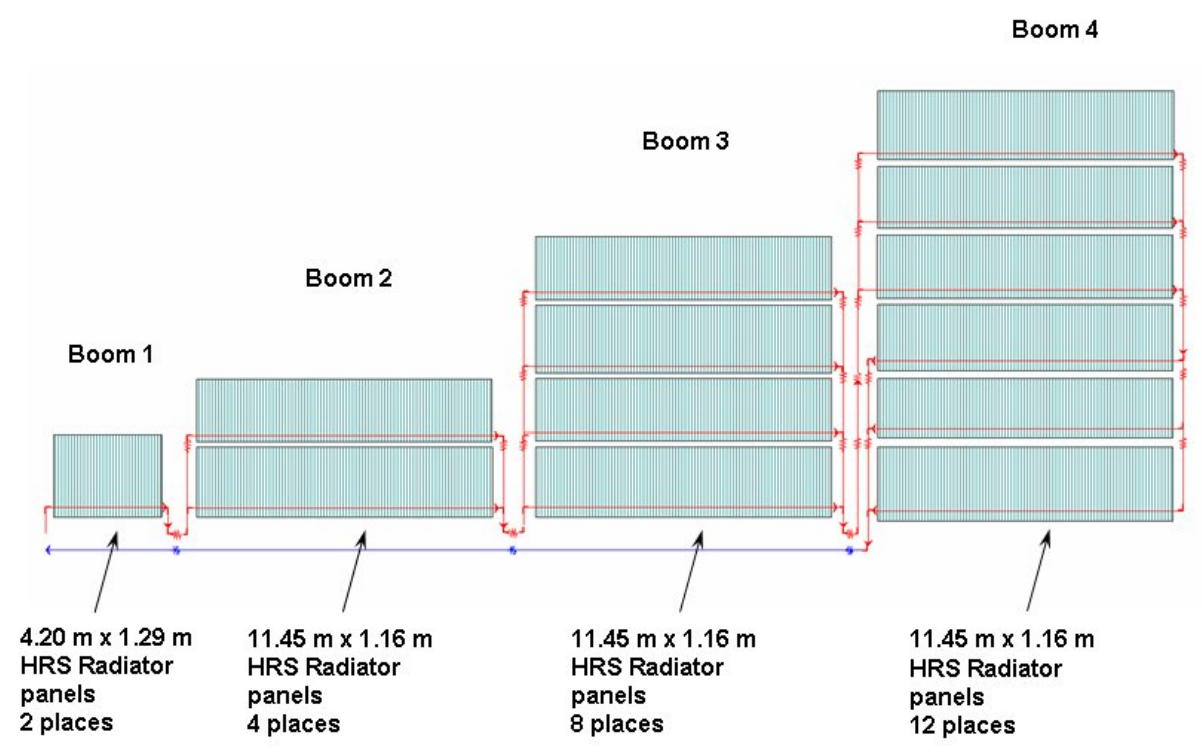

Figure 6.-Updated HRS radiator geometry.

\section{HRS Design Parameters}

The Brayton HRS described in the previous design study (Siamidis, 2005) specified the primary thermal design requirements and configuration. These parameters were updated according to the latest HRS design. Table 1 includes the major parameter changes from the previous design study to the updated HRS design, one-half of which is shown in figure 6.

Additional design details were needed before a substantive evaluation of the HRS trade space could be performed. This included a preliminary definition of construction materials and some of the dimensional parameters. For this study, these parameters were held constant, although the model allows them to be varied. The heat pipes were assumed to use water with a 10 percent liquid fill fraction. The assumed heat pipe containment was titanium $\left(4.5 \mathrm{~g} / \mathrm{cm}^{3}\right)$. The thermal saddles were assumed to be made of $0.54 \mathrm{~g} / \mathrm{cm}^{3}$ Poco graphite. The facesheets were carbon-carbon with a density of $1.92 \mathrm{~g} / \mathrm{cm}^{3}$ and thermal conductivity (normal to the direction of the heat pipes) varying as a function of temperature. The coolant duct was titanium with wall-thickness and cross-section given in table 1 . The duct supply and return length for the $\mathrm{H}_{2} \mathrm{O}(\sim 365 \mathrm{~m})$ is greater than that of $\mathrm{NaK}(\sim 200 \mathrm{~m})$ due to its split design as seen in figure 5 .

TABLE 1.-DESIGN PARAMETER CHANGES

\begin{tabular}{lcc}
\hline Parameter & $\begin{array}{c}\text { Previous design study } \\
\text { (Siamidis, 2005) HRS }\end{array}$ & Updated HRS \\
\hline Radiator heat load $(\mathrm{kWt})$ & 364 & $590+5$ percent margin \\
Radiator inlet temperature $(\mathrm{K})$ & 556 & 507 \\
Radiator exit temperature $(\mathrm{K})$ & 399 & 387 \\
Radiator area $\left(\mathrm{m}^{2}\right)$ & $170($ includes $10 \%$ margin) & $422($ includes $10 \%$ margin) \\
Duct wall-thickness $(\mathrm{cm})$ & $0.05 \mathrm{~cm}(\mathrm{NaK}-55)$ & $0.075(\mathrm{NaK}-55)$ and $0.15\left(\mathrm{H}_{2} \mathrm{O}\right)$ \\
Duct cross section $\left(\mathrm{cm}^{2}\right)$ & Square $(\mathrm{NaK}-55)$ & Oval $(\mathrm{NaK}-55)$ and $\mathrm{Circular}\left(\mathrm{H}_{2} \mathrm{O}\right)$ \\
Duct supply and return length $(\mathrm{m})$ & $\sim 50$ & $200(\mathrm{NaK}-55)$ and $\sim 365\left(\mathrm{H}_{2} \mathrm{O}\right)$ \\
HP Tube wall thickness $(\mathrm{cm})$ & 0.05 & 0.07 \\
Carbon-carbon facesheet in-plane & 600 & Function of temperature \\
thermal conductivity $(\mathrm{W} / \mathrm{m}-\mathrm{K})$ & 0.10 & 0.375 \\
Heat pipe saddle min. thickness $(\mathrm{cm})$ & $15 \%(\mathrm{NaK}-55)$ & $20 \%(\mathrm{NaK}-55)$ and $30 \%\left(\mathrm{H}_{2} \mathrm{O}\right)$ \\
Pump efficiency & &
\end{tabular}




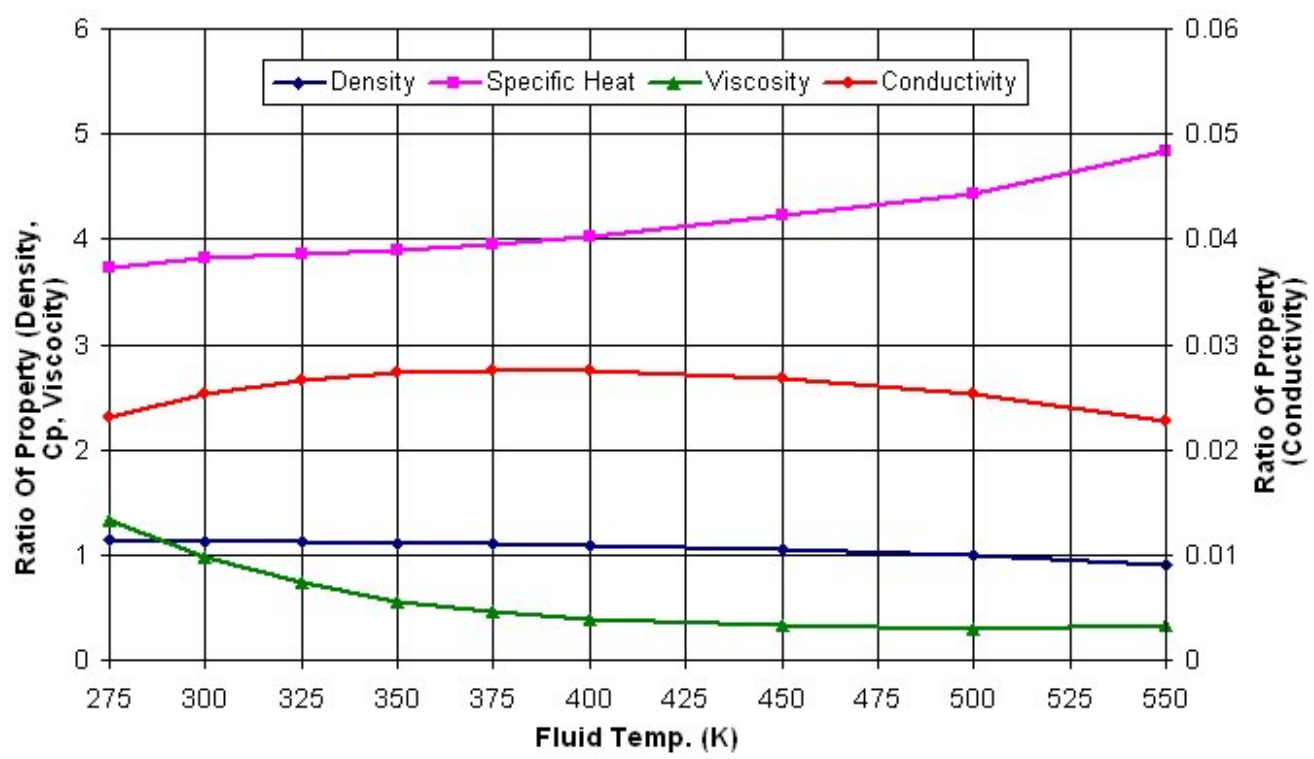

Figure 7.- $-\mathrm{NaK}-55$ and $\mathrm{H}_{2} \mathrm{O}$ fluid property ratios for $\mathrm{H}_{2} \mathrm{O} / \mathrm{NaK}-55$.

The primary emphasis of this study is coolant fluid selection and its effect on overall HRS performance. The coolant used in the previous design study analysis was NaK-78. This analysis compares NaK-55 with $\mathrm{H}_{2} \mathrm{O}$. NaK-55 was chosen over NaK-78 for its lower freeze-temperature $(280 \mathrm{~K})$ and higher specific heat. Higher specific heat reduces fluid mass flow rate and higher liquid density reduces fluid volumetric flow-rate, which in turn reduce fluid loop mass and pumping power. A comparison of the thermal properties of NaK-55 and $\mathrm{H}_{2} \mathrm{O}$ are shown in figure 7 where the ratios of $\mathrm{H}_{2} \mathrm{O} / \mathrm{NaK}-55$ properties are plotted versus fluid temperature. Other factors to consider in evaluating the two fluids are listed in table 2.

TABLE 2.- NaK-55 AND $\mathrm{H}_{2} \mathrm{O}$ DIFFERENCES

\begin{tabular}{|c|c|}
\hline NaK-55 & $\mathrm{H}_{2} \mathrm{O}$ \\
\hline $\begin{array}{l}\text { Alkali metal, health and safety hazard } \\
\text { - Requires non-standard handling procedures in crewed } \\
\text { environments } \\
\text { - Requires careful cleaning procedures prior to assembly } \\
\text { and test }\end{array}$ & $\begin{array}{l}\text { Common material, no health hazards } \\
\text { - No special handling procedures required }\end{array}$ \\
\hline $\begin{array}{l}\text { Moderate specific-heat } \\
\text { - Efficient single-phase pumped fluid option }\end{array}$ & $\begin{array}{l}\text { Extremely high specific-heat } \\
\text { - Very efficient single-phase fluid option } \\
\text { - } \quad \text { Specific-heat approximately four (4) times that of NaK-55 }\end{array}$ \\
\hline $\begin{array}{l}\text { High thermal conductivity } \\
\text { - Very small }(\sim 1 \mathrm{~K}) \text { fluid to wall temperature difference } \\
\text { Low vapor pressure } \\
\text { - Allows thinner and lighter fluid loop components } \\
\text { High electrical conductivity } \\
\text { - Eddy current losses reduce mechanical pump efficiency to } \\
\text { - Well suited for Electromagnetic Magnetic (EM) pumping } \\
\quad \text { options, pumping efficiency typically }<15 \% \text { net }\end{array}$ & $\begin{array}{l}\text { Low thermal conductivity } \\
\text { - Small }(\sim 6 \mathrm{~K}) \text { fluid to wall temperature difference } \\
\text { High vapor pressure } \\
\text { - Requires thicker and more robust fluid loop components } \\
\text { Low electrical conductivity } \\
\text { - Highly efficient }(>30 \%) \text { mechanical-pumps } \\
\text { - } \quad \text { Electromagnetic Magnetic }(\mathrm{EM}) \text { pumping not an option }\end{array}$ \\
\hline
\end{tabular}

Other design variables considered in this study were heat pipe spacing and system pressure drop. The range of parameters considered is provided in table 3. Given the seven different spacing options and three system pressure drops for each fluid, a total of forty-two individual design cases were examined. The 
primary output parameter of interest was the total HRS mass. The total HRS mass includes the radiator panel mass, and the fluid loop mass with ducts, pumps, accumulators, and other miscellaneous components such as flexible fluid joints.

TABLE 3.-DESIGN VARIABLES USED IN STUDY

\begin{tabular}{lcc}
\hline \multicolumn{1}{c}{ Parameter } & Value & Basis \\
\hline Coolant fluid & $\mathrm{Nak}-55, \mathrm{H}_{2} \mathrm{O}$ & Input \\
Heat pipe spacing $(\mathrm{cm})$ & $7,8,9,10,11,12,13$ & Input \\
Heat pipe inner diameter $(\mathrm{cm})$ & 1.25 & Input \\
Fluid duct system pressure drop $(\mathrm{kPa})$ & $100,200,300$ & Input \\
Pump efficiency $(\%)$ & $20 \% \mathrm{NaK}, 30 \% \mathrm{H}_{2} \mathrm{O}$ & Input \\
Radiator area $\left(\mathrm{m}^{2}\right)$ & $422($ Includes $10 \%$ margin) & Input \\
Facesheet thickness $(\mathrm{mm})$ & Varied & Input \\
Duct size $\left(\mathrm{NaK}: \mathrm{W} \times \mathrm{H}, \mathrm{H}_{2} \mathrm{O}: \mathrm{Dia}\right)(\mathrm{cm} \mathrm{x} \mathrm{cm}, \mathrm{cm})$ & Varied & Input \\
HRS mass $(\mathrm{kg})$ & & Calculated \\
Total pump power $(\mathrm{W})$ & & Calculated \\
\hline
\end{tabular}

Once the forty-two individual design cases were analyzed, the minimum mass design point was used to further investigate the effect of different radiator inlet and outlet temperatures on the HRS mass for a fixed system pressure drop of $200 \mathrm{kPa}$. Table 4 provides the additional cases analyzed.

TABLE 4.-ADDITIONAL DESIGN VARIABLES USED IN STUDY

\begin{tabular}{lccc}
\hline \multicolumn{1}{c}{ Parameter } & Design Point & Design Point $\mathbf{- 2 5}$ K & Design Point +25 K \\
\hline HRS coolant inlet temperature (K) & 507 & 482 & 532 \\
HRS coolant outlet temperature (K) & 387 & 362 & 412 \\
HRS coolant DT (K) & 120 & 120 & 120 \\
\hline
\end{tabular}

\section{Analytical Results}

The process used to analyze each configuration was as follows. A heat pipe spacing and heat pipe inner diameter was selected. An iterative process of varying three parameters then followed. The facesheet thickness was adjusted until the radiator coolant exit temperature reached the required value of $387 \mathrm{~K}$ and the radiator heat load matched the required value of $590 \mathrm{kWt}$. At the same time, the duct size and heat pipe evaporator length were varied to achieve the assigned system pressure drop (100, 200, and $300 \mathrm{kPa}$ ) and the $10 \mathrm{~W} / \mathrm{cm}^{2}$ evaporator radial flux limit respectively.

A sample case is reported in table 5 for $10 \mathrm{~cm}$ heat pipe spacing and a $1.25 \mathrm{~cm}$ heat pipe inner diameter. The resulting facesheet thickness required to achieve the $387 \mathrm{~K}$ radiator exit temperature was $0.25 \mathrm{~mm}$. The heat pipe geometry and facesheet thickness resulted in a fin efficiency of 79 percent. The required pump system pressure drop was set at $200 \mathrm{kPa}$ which resulted in a pump power of $478 \mathrm{~W}$ for each pump. The maximum heat pipe power and radial flux was $456 \mathrm{~W}$ and $10 \mathrm{~W} / \mathrm{cm}^{2}$, respectively. The total HRS mass was $1511 \mathrm{~kg}$ or $7.16 \mathrm{~kg} / \mathrm{m}^{2}$ (based on total surface area), and the radiator panel areal mass was $3.27 \mathrm{~kg} / \mathrm{m}^{2}$ (based on total surface area). 
TABLE 5.-SAMPLE RESULTS CASE

\begin{tabular}{lcc}
\hline Parameter & Value & Basis \\
\hline Coolant fluid & $\mathrm{H}_{2} \mathrm{O}$ & Input \\
Coolant inlet temperature $(\mathrm{K})$ & 507 & Input \\
Coolant outlet temperature $(\mathrm{K})$ & 387 & Input \\
Heat pipe spacing $(\mathrm{cm})$ & 10 & Input \\
Heat pipe inner diameter $(\mathrm{cm})$ & 1.25 & Input \\
Facesheet thickness $(\mathrm{mm})$ & 0.25 & Input \\
Pump system pressure drop $(\mathrm{kPa})$ & 200 & Input \\
Fin efficiency $(\%)$ & $79 \%$ & Calculated \\
Total pump power $(\mathrm{W})$ & 478 & Calculated \\
MAX heat pipe power $(\mathrm{W})$ & 456 & Calculated \\
MAX heat pipe radial flux $\left(\mathrm{W} / \mathrm{cm}^{2}\right)$ & 10.0 & Calculated \\
Total radiator panel mass $(\mathrm{kg})$ & 689.7 & Calculated \\
Total heat transport mass $($ with pumps and accumulators) $(\mathrm{kg})$ & 821.3 & Calculated \\
Total HRS mass $(\mathrm{kg})$ & 1511.00 & Calculated \\
Radiator panel areal mass—-single sided $\left(\mathrm{kg} / \mathrm{m}^{2}\right)$ & 3.27 & Calculated \\
Total HRS areal mass_-single sided $\left(\mathrm{kg} / \mathrm{m}^{2}\right)$ & 7.16 & Calculated \\
\hline
\end{tabular}

Based on the results of this paper, there is substantial mass savings for a $\mathrm{H}_{2} \mathrm{O}$ system versus a NaK-55 system for the given radiator temperatures. The mass savings is a function of several parameters including the system pressure drop and the radiator inlet temperature. The mass savings lessens with increases in system pressure drop or radiator inlet temperature.

Figure 8 shows the variance of the HRS radiator, fluid loop and total mass as a function of heat pipe spacing for a heat pipe inner diameter of $1.25 \mathrm{~cm}$ and pump system pressure drop of $200 \mathrm{kPa}$ for both NaK-55 and $\mathrm{H}_{2} \mathrm{O}$ coolants. Results show that the minimum mass HRS occurs at a heat pipe spacing of about $10 \mathrm{~cm}$ for both coolants. Results also show that an $\mathrm{HRS}$ with $\mathrm{H}_{2} \mathrm{O}$ weights about $230 \mathrm{~kg}$ less than an HRS with NaK-55 at the minimum mass design point for the given parameters. Similar trends were predicted for pump system pressure drops of 100 and $300 \mathrm{kPa}$.

Figure 9 shows the variation of the total HRS mass, fluid loop mass, and radiator mass as a function of pump system pressure drop for a heat pipe spacing of $10 \mathrm{~cm}$ and heat pipe inner diameter of $1.25 \mathrm{~cm}$. Pressure drop was varied by changing the duct cross-section. Overall duct length and mass flow rate were held constant. A smaller duct size increases the pressure drop, but reduces the duct mass, fluid inventory and fluid mass. Increasing the system pressure drop from 100 to $300 \mathrm{kPa}$, results in a weight saving of approximately $200 \mathrm{~kg}$ for the NaK-55 system and $150 \mathrm{~kg}$ for the $\mathrm{H}_{2} \mathrm{O}$ system.

A HRS with a $\mathrm{H}_{2} \mathrm{O}$ fluid loop weighs less than its NaK-55 counterpart, and this weight saving benefit is slightly affected by pump system pressure drop. The weight benefit realized through $\mathrm{H}_{2} \mathrm{O}$ is due primarily to differences within the fluid loops and only marginally affected by differences in the radiator itself. While a $\mathrm{H}_{2} \mathrm{O}$ system requires heavier ducts to withstand the higher pressures as compared to NaK55 , an overall weight saving is seen due to the smaller duct size and lower fluid inventory. The weight benefit of an $\mathrm{H}_{2} \mathrm{O}$-based HRS is reduced somewhat as the pump system pressure drop increases. As the system pressure drop increases from 100 to 200 to $300 \mathrm{kPa}$, the mass savings of the $\mathrm{H}_{2} \mathrm{O}$ system decreases from 265 to 227 to $210 \mathrm{~kg}$, respectively.

The second part of the analysis evaluated performance sensitivities with variable inlet and exit temperatures. For each case, the heat pipe spacing and the heat pipe inner diameter were given fixed values. Then, the facesheet thickness was varied until the radiator coolant exit temperature reached the desired value and the radiator heat load matched the design value of $590 \mathrm{kWt}$. 


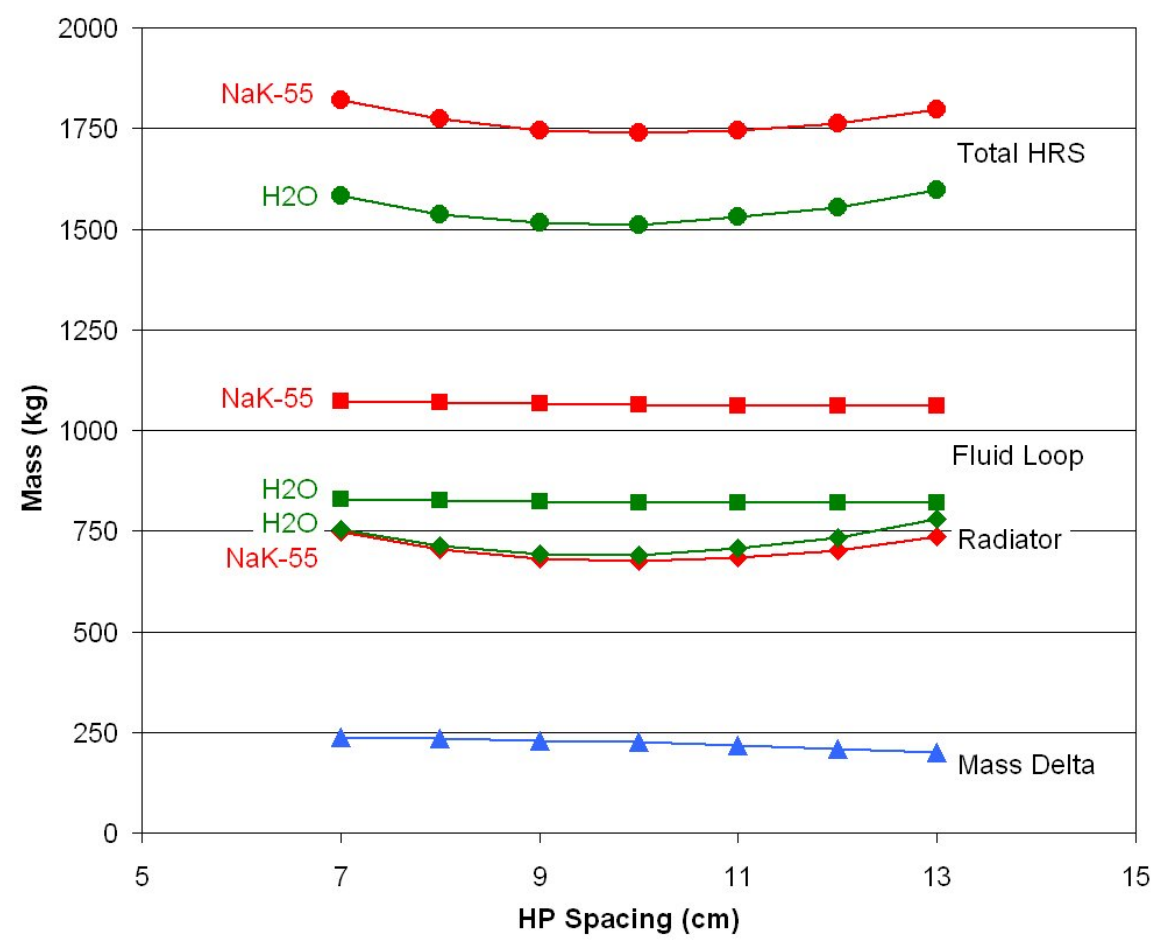

Figure 8. - HRS mass versus heat pipe spacing - $200 \mathrm{kPa}$.

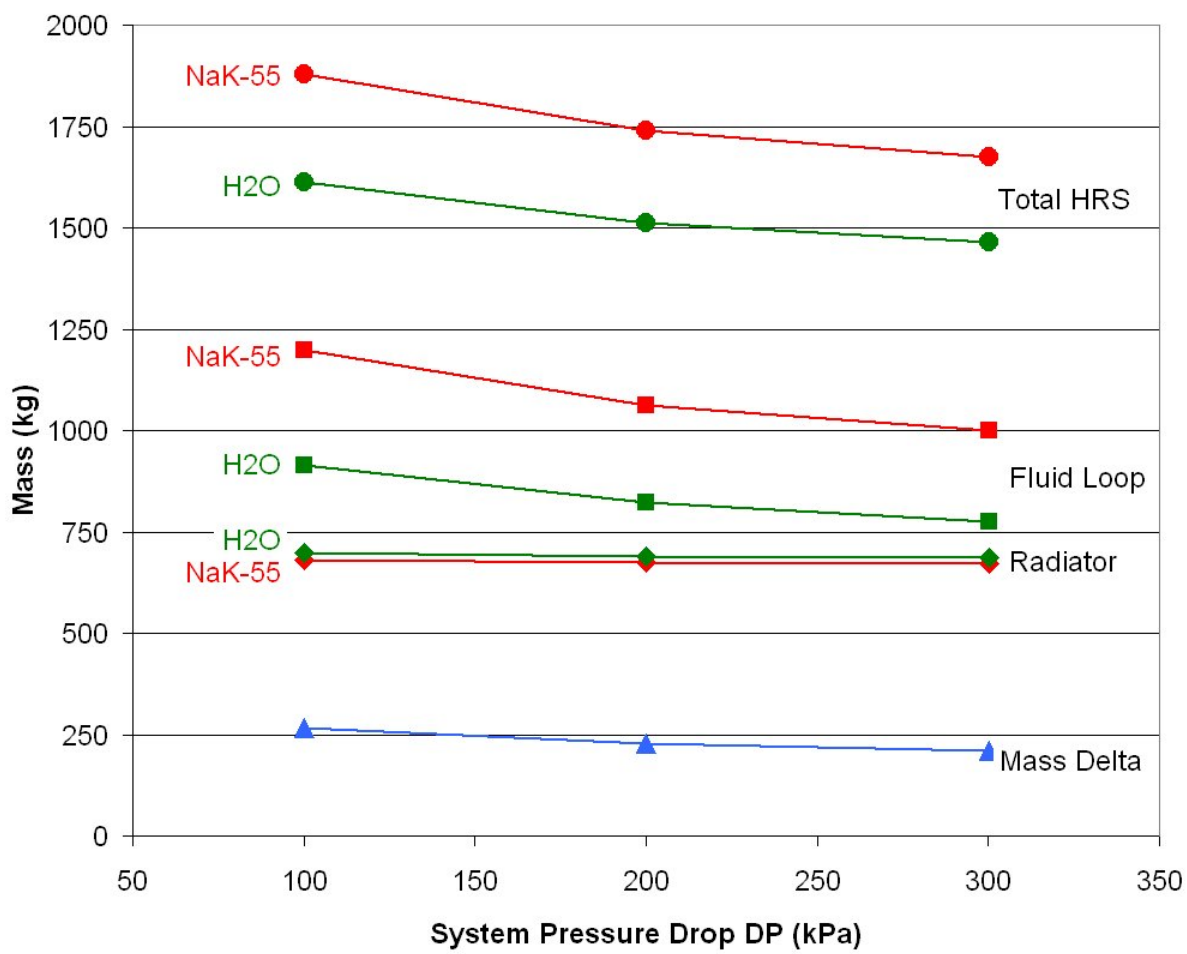

Figure 9.- HRS mass versus system pressure drop. 
Figure 10 shows the variation of the HRS radiator, fluid loop, and total mass as a function of radiator inlet temperature for a heat pipe spacing of $10 \mathrm{~cm}$, heat pipe inner diameter of $1.25 \mathrm{~cm}$, and system pressure drop of $200 \mathrm{kPa}$ with both NaK-55 and $\mathrm{H}_{2} \mathrm{O}$ coolants. There is a significant mass decrease with increasing temperature due to the reduction in radiator surface area. The reduced area permitted decreases in the duct supply and return lengths, allowing the duct cross-section to be reduced commensurately given the assumption of fixed pressure drop. The higher temperatures did cause an increase in duct wall thickness as required for the elevated operating pressures. As the radiator inlet temperature increases from 482 to 507 to $532 \mathrm{~K}$, the mass savings of the $\mathrm{H}_{2} \mathrm{O}$ system decreases from 388 to 227 to $38 \mathrm{~kg}$, respectively. The mass advantage for water is less pronounced at higher temperature since the duct wall increases are exacerbated by the much higher operating pressures.

Figure 11 shows the variance of the HRS radiator area as a function of radiator inlet temperature for a heat pipe spacing of $10 \mathrm{~cm}$, heat pipe inner diameter of $1.25 \mathrm{~cm}$ and pump system pressure drop of $200 \mathrm{kPa}$ for both NaK-55 and $\mathrm{H}_{2} \mathrm{O}$ coolants. Results show that the HRS area (same for both NaK-55 and $\mathrm{H}_{2} \mathrm{O}$ coolants) decreases as the radiator inlet temperature increases. An HRS with a radiator inlet temperature of $530 \mathrm{~K}$ has 35 percent less area than an HRS with a radiator inlet temperature of $480 \mathrm{~K}$.

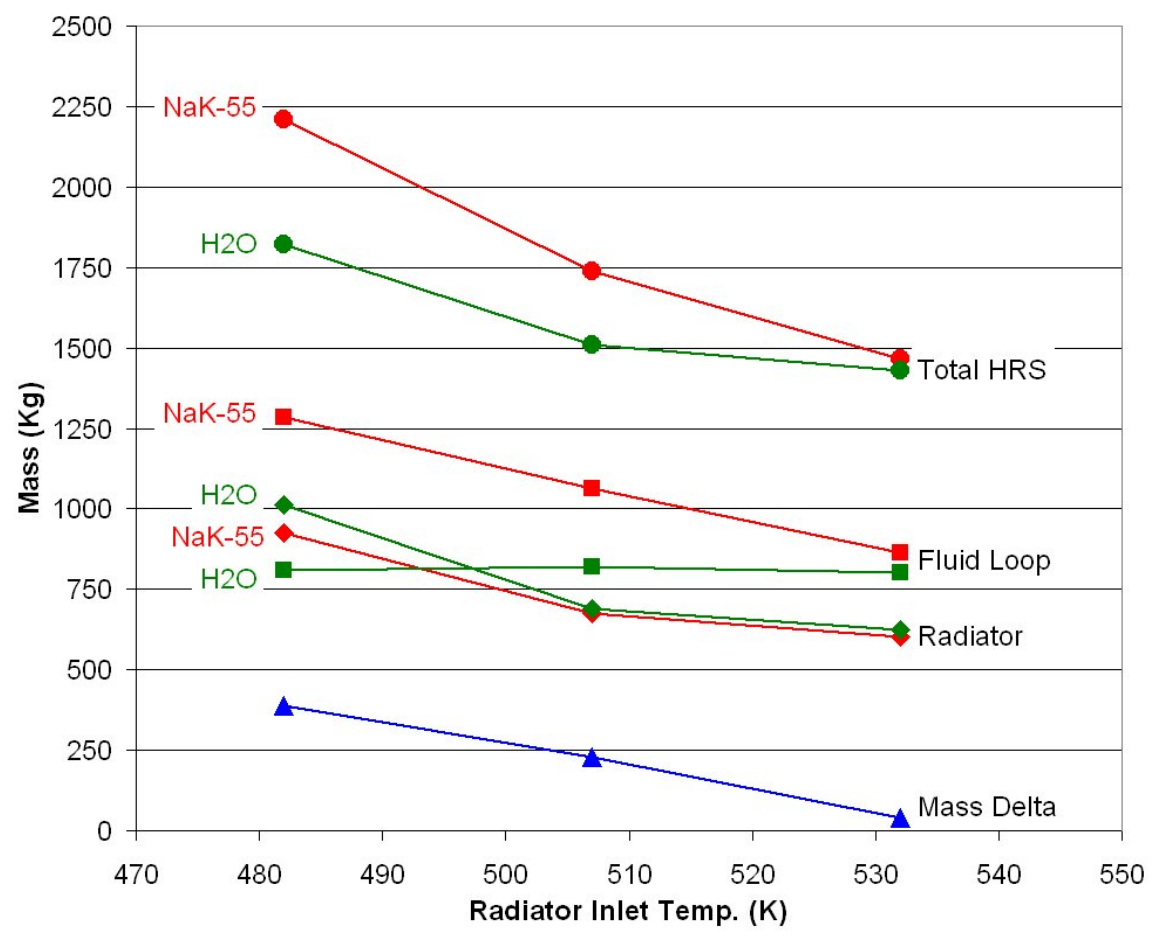

Figure 10.- HRS mass versus radiator inlet temperature. 


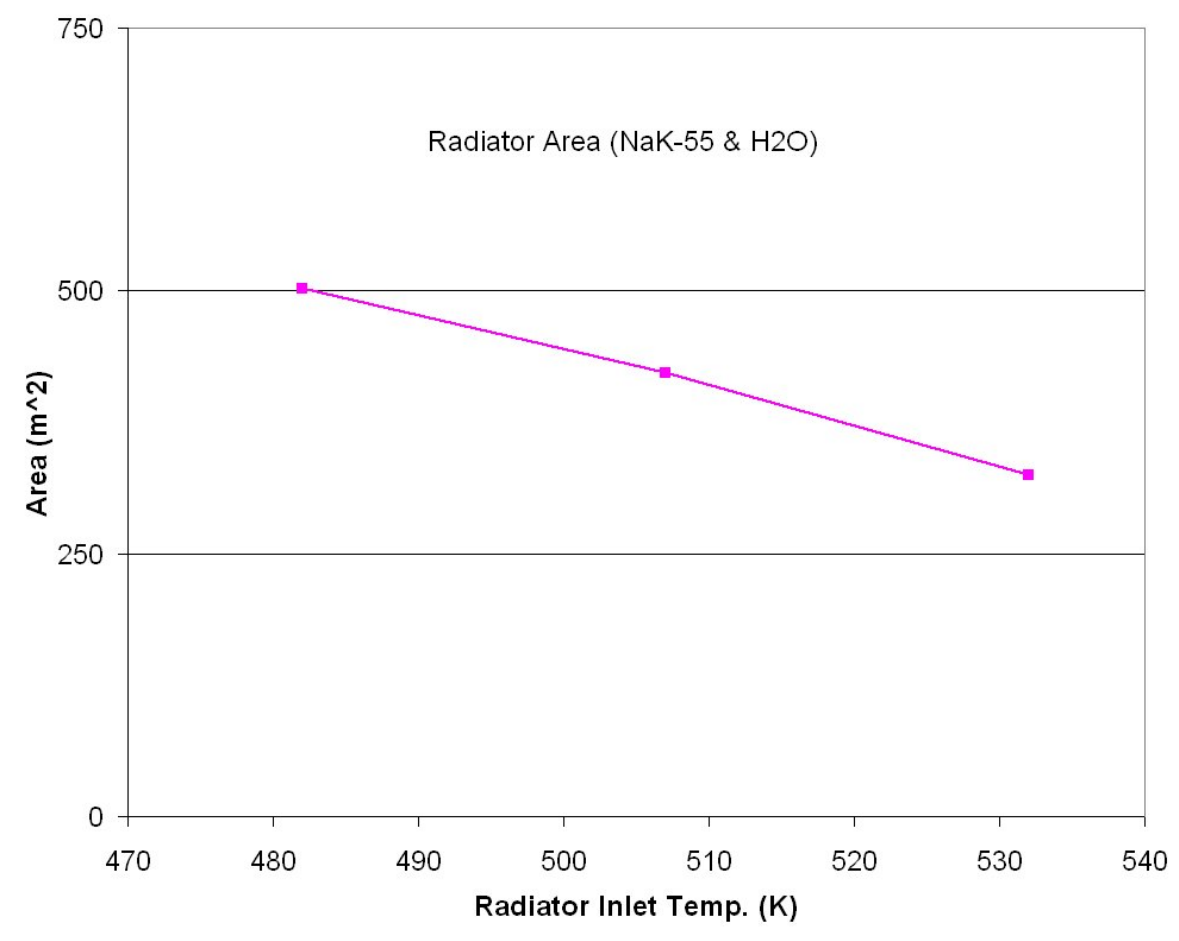

Figure 11.- - HRS area versus radiator inlet temperature.

\section{Conclusions and Recommendations}

Earlier HRS design trades were conducted addressing heat transport approaches, material and fluid options, and deployed radiator geometries. This paper discusses the interplay between radiator coolants (NaK-55 and $\mathrm{H}_{2} \mathrm{O}$ ) for various heat pipe spacings and pump system pressure drops for a fixed geometry radiator. It also discussed the interplay between radiator coolants $\left(\mathrm{NaK}-55\right.$ and $\left.\mathrm{H}_{2} \mathrm{O}\right)$ for various radiator coolant inlet temperatures for a fixed heat pipe spacing and fixed pump pressure drop system.

Based on the results of this paper, there is substantial mass savings for a $\mathrm{H}_{2} \mathrm{O}$ system over a NaK-55 system for the given radiator temperatures. This mass savings is a function of the system pressure drop and the radiator inlet temperature. The mass savings for the $\mathrm{H}_{2} \mathrm{O}$ system decreases as the system pump pressure drop increases and as the radiator inlet temperature increases.

Additional trade studies are needed to further refine the HRS design and make the choice between NaK-55 and $\mathrm{H}_{2} \mathrm{O}$ final. Other considerations must be taken into account in addition to the mass savings. These should include, but not be limited to:

- Health and safety issues (toxic $\mathrm{NaK}$ vs. for non-toxic/non-hazardous water).

- Technology development ( $\mathrm{NaK}$ fluid loop requires extensive technology development).

- Compatibility issues (NaK may have long-term) compatibility issues with fluid loop materials.

- System Packaging (NaK fluid loop requires larger fluid and flex-hose diameters, complicates mechanical packaging, water fluid loop requires smaller fluid and flex-hose diameters, simplifies mechanical packaging).

- Structural design and Integrity (low pressure $\mathrm{NaK}$ fluid vs. high pressure $\mathrm{H}_{2} \mathrm{O}$ system). 


\section{References}

Gilmore, D.G., Satellite Thermal Control Handbook, The Aerospace Corporation Press, El Segundo, California, 1994, pp. 133-134.

J.P. Holman, Heat Transfer, 5th Edition, McGraw-Hill, 1981, pp. 210-211.

Mason, L.S., "A Power Conversion Concept for the Jupiter Icy Moons Orbiter," AIAA-2003-6007, 2003.

Siamidis, J., "Heat Rejection Concepts for Brayton Power Conversion Systems," AIAA-2004-5654, 2005. 


\section{Appendix-Nomenclature}

$T \quad$ Temperature (K)

$\Delta P \quad$ Pressure drop $(\mathrm{kPa})$

$f \quad$ Friction factor

$L \quad$ Length (m)

$d \quad$ Diameter (m)

r Liquid density $\left(\mathrm{kg} / \mathrm{m}^{3}\right)$

$u \quad$ Velocity $(\mathrm{m} / \mathrm{s})$ 
Public reporting burden for this collection of information is estimated to average 1 hour per response, including the time for reviewing instructions, searching existing data sources, gathering and maintaining the data needed, and completing and reviewing the collection of information. Send comments regarding this burden estimate or any other aspect of this collection of information, including suggestions for reducing this burden, to Washington Headquarters Services, Directorate for Information Operations and Reports, 1215 Jefferson Davis Highway, Suite 1204, Arlington, VA 22202-4302, and to the Office of Management and Budget, Paperwork Reduction Project (0704-0188), Washington, DC 20503.

\begin{tabular}{|l|l|l}
\hline 1. AGENCY USE ONLY (Leave blank) & $\begin{array}{c}\text { 2. REPORT DATE } \\
\text { February } 2006\end{array}$ & $\begin{array}{r}\text { 3. REPORT TYPE AND DATES COVERED } \\
\text { Technical Memorandum }\end{array}$ \\
\hline
\end{tabular}

4. TITLE AND SUBTITLE 5. FUNDING NUMBERS

A Comparison of Coolant Options for Brayton Power Conversion Heat Rejection Systems

6. AUTHOR(S)

John Siamidis and Lee S. Mason

WBS-22-982-10-30

7. PERFORMING ORGANIZATION NAME(S) AND ADDRESS(ES)

National Aeronautics and Space Administration

John H. Glenn Research Center at Lewis Field

Cleveland, Ohio 44135-3191

8. PERFORMING ORGANIZATION REPORT NUMBER

E-15456

9. SPONSORING/MONITORING AGENCY NAME(S) AND ADDRESS(ES)

10. SPONSORING/MONITORING AGENCY REPORT NUMBER

National Aeronautics and Space Administration

Washington, DC 20546-0001

NASA TM-2006-214121

\section{SUPPLEMENTARY NOTES}

Prepared for the Space Technology and Applications International Forum (STAIF-2006) sponsored by the University of New Mexico's Institute for Space and Nuclear Power Studies (UNM-ISNPS), Albuquerque, New Mexico, February 12-16, 2006. John Siamidis, Analex Corporation, 1100 Apollo Drive, Brook Park, Ohio 44142; and Lee S. Mason, NASA Glenn Research Center. Responsible person, John Siamidis, organization code RPT, 216-433-3151.

12a. DISTRIBUTION/AVAILABILITY STATEMENT

12b. DISTRIBUTION CODE

Unclassified - Unlimited

Subject Category: 20

Available electronically at http://gltrs.grc.nasa.gov

This publication is available from the NASA Center for AeroSpace Information, 301-621-0390.

13. ABSTRACT (Maximum 200 words)

This paper describes potential heat rejection design concepts for Brayton power conversion systems. Brayton conversion systems are currently under study by NASA for Nuclear Electric Propulsion (NEP) and surface power applications. The Brayton Heat Rejection Subsystem (HRS) must dissipate waste heat generated by the power conversion system due to inefficiencies in the thermal-to-electric conversion process. Sodium potassium $(\mathrm{NaK})$ and $\mathrm{H}_{2} \mathrm{O}$ are two coolant working fluids that have been investigated in the design of a

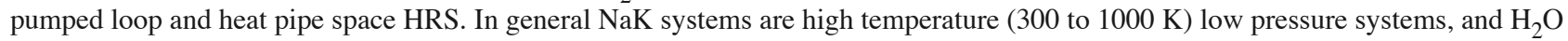
systems are low temperature ( 300 to $600 \mathrm{~K}$ ) high pressure systems. $\mathrm{NaK}$ is an alkali metal with health and safety hazards that require special handling procedures. On the other hand, $\mathrm{H}_{2} \mathrm{O}$ is a common fluid, with no health hazards and no special handling procedures. This paper compares $\mathrm{NaK}$ and $\mathrm{H}_{2} \mathrm{O}$ for the HRS pumped loop coolant working fluid. A detailed Microsoft ${ }^{\circledR}$ Excel (Microsoft Corporation, Redmond, WA) analytical model, HRS_Opt, was developed to evaluate the various HRS design parameters. It is capable of analyzing $\mathrm{NaK}$ or $\mathrm{H}_{2} \mathrm{O}$ coolant, parallel or series flow configurations, and numerous combinations of other key parameters (heat pipe spacing, diameter and radial flux, radiator facesheet thickness, fluid duct system pressure drop, system rejected power, etc.) of the HRS. This paper compares NaK against water for the HRS coolant working fluid with respect to the relative mass, performance, design and implementation issues between the two fluids.

14. SUBJECT TERMS

Brayton power conversion system; Brayton heat rejection system; Heat pipe radiator 15. NUMBER OF PAGES 21

\begin{tabular}{|c|c|c|}
\hline $\begin{array}{c}\text { 17. SECURITY CLASSIFICATION } \\
\text { OF REPORT } \\
\text { Unclassified }\end{array}$ & $\begin{array}{c}\text { 18. SECURITY CLASSIFICATION } \\
\text { OF THIS PAGE } \\
\text { Unclassified }\end{array}$ & $\begin{array}{c}\text { 19. SECURITY CLASSIFICATION } \\
\text { OF ABSTRACT } \\
\text { Unclassified }\end{array}$ \\
\hline
\end{tabular}



